\title{
FEEDING BEHAVIOUR AND THE OPERCULUM IN OLIVIDAE (GASTROPODA): THE CASE OF CALLIANAX BIPLICATA (G. B. SOWERBY I, 1825)
}

\author{
Molly Kelly ${ }^{1}$, Linda SchroedeR ${ }^{2}$, DANiel L. Mullendore ${ }^{3}$, Benjamin F. DatTilo ${ }^{1}$, \\ WINFRIED S. PETERS ${ }^{1,3,4 *}$
}
${ }^{1}$ Purdue University Fort Wayne, Department of Biology, 2101 Coliseum Boulevard, Fort Wayne, IN 46805, USA (e-mails: dattilob@pfw.edu; petersw@pfw.edu); (1) BFD https://orcid.org/0000-0002-2917-6777, (1) WSP https://orcid.org/0000-0002-5061-1497
${ }^{2}$ Pacific Northwest Shell Club (PNWSC.org), Seattle, WA, USA
${ }^{3}$ Washington State University, School of Biological Science, Abelson Hall, Pullman, WA 99164, USA
(e-mail: mullendore@wsu.edu)
${ }^{4}$ Goldring-Gund Marine Biology Station, Playa Grande, Santa Cruz, Guanacaste, Costa Rica
*corresponding author

\begin{abstract}
Olividae are marine gastropods living as predators or scavengers on soft sediments. The complex prey handling behaviour of large predatory species includes the storage of food in a pouch formed temporarily by bending and contraction of the posterior foot. Such metapodial pouches had been observed only in Olividae that lack an operculum, prompting the hypothesis that the folding of the metapodium into a pouch biomechanically required the absence of the operculum. Here we report metapodial pouch formation in an operculate olivid, Callianax biplicata (formerly Olivella biplicata). Since the operculum is too small to close the shell aperture in mature $C$. biplicata, a protective function seems unlikely. The operculum may rather serve as an exoskeletal point for muscle attachment, but may also represent a 'vestigial organ' in the process of evolutionary reduction, or an ontogenetic remnant functional at early life stages but not at maturity. Consequently, our observations refute the notion that only inoperculate olivids can form pouches, but not necessarily the idea that the ability to form a metapodial pouch evolved in parallel with operculum reduction.
\end{abstract}

KEY WORDS: biomechanics; Callianax; Olividae; metapodial pouch; operculum; vestigial organ

\section{INTRODUCTION}

Olive shells are marine gastropods which mostly live as scavengers and predators on soft sediments in shallow marine and intertidal habitats (ZEIGLER \& PorreCA 1969, TURSCH \& GREIFENEDER 2001). Because of their size and appealing appearance, the shells are sought after by collectors (STERBA 2004). The resulting tendency to describe even minor variations as new taxa has contributed to considerable taxonomic confusion, especially in the large genus Oliva (TURSCH \& GREIFENEDER 2001). The most recent revision of olive shell systematics subdivided the superfamily Olivoidea (Caenogastropoda, Neogastropoda) into five taxa of family rank (KANTOR et al. 2017). Of these families, the Olividae are the largest with about 270 species, more than half of all the species in the Olivoidea (MOlLUSCABASE 2020). Molecular data further suggested the division of the Olividae into four subfamilies: Olivinae, Calyptolivinae, Agaroniinae, and Olivellinae (KANTOR et al. 2017; Fig. 1 ). The inclusion of the Olivellinae was not necessarily expected, as this taxon, which consists of comparatively small species (OLSSON 1956), previously had been listed as a family of its own (Olivellidae; KANTOR 1991, BOUCHET \& ROCROI 2005). Both the 
maximum likelihood and Bayesian analysis of the available sequence data of four genes suggested the Olivinae as the sister group of a clade comprising the other three subfamilies, and within that clade the Olivellinae as the sister group of the Agaroniinae (Fig. 1; see also KANTOR et al. 2017: figs 3, 4).

Predatory Olividae show complex hunting behaviour, as has been described for several Oliva spe-
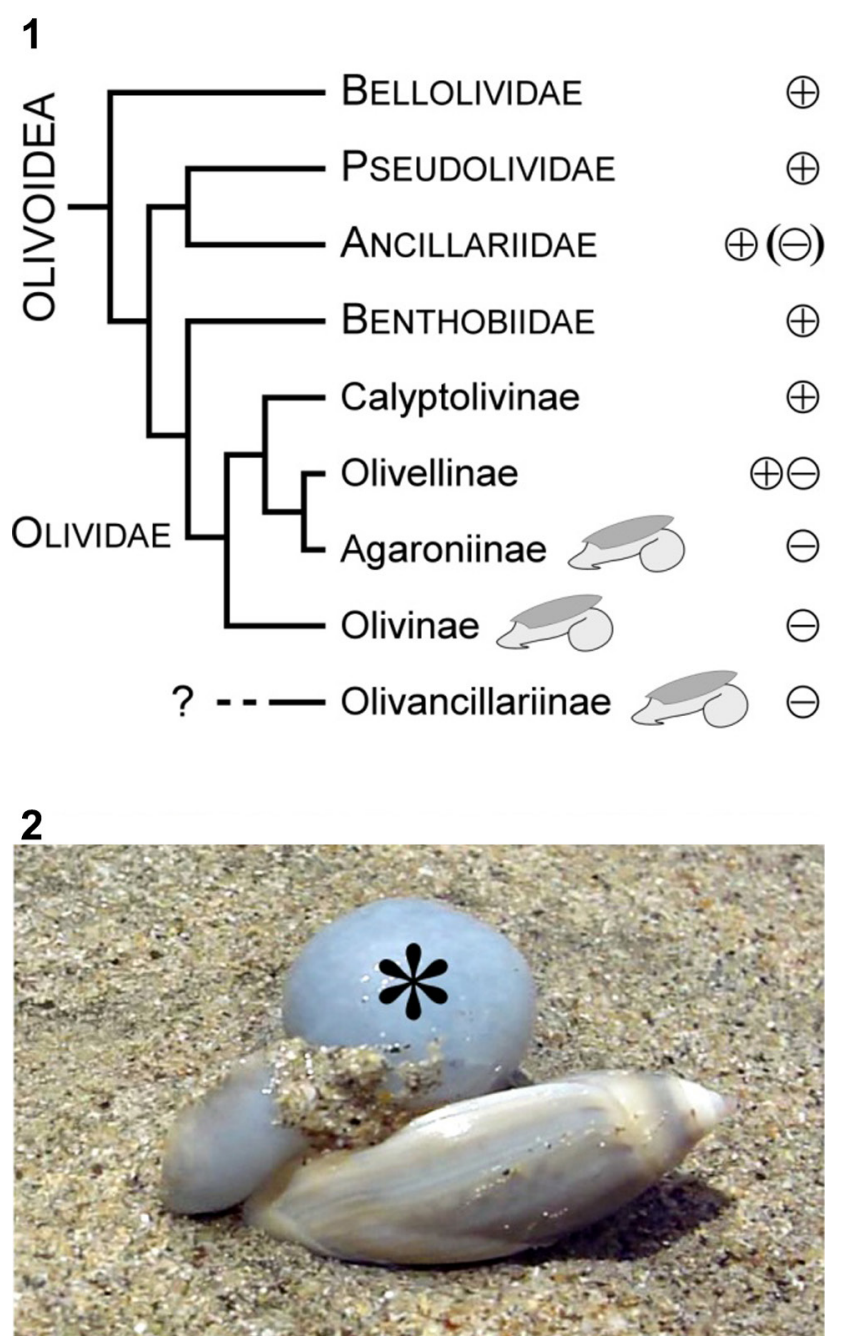

Figs 1-2. In olivid gastropods, the habit of storing food in a pouch formed by the posterior metapodium appears to correlate with the lack of an operculum: 1 - Simplified model of the phylogenetic hypothesis concerning the superfamily Olivoidea by KANTOR et al. (2017). Cladistic relationships between the five recognised families in the Olivoidea and the subfamily structure of the Olividae are shown. The Olivancillariinae were not included in the analysis, but may represent a fifth subfamily of the Olividae. The Agaroniinae, Olivinae, and Olivancillariinae are predators known to store captured prey in a metapodial pouch (compare Fig. 2), as highlighted by the cartoons. In these three taxa, opercula are generally missing. Opercula are absent also in some Olivellinae and a few Ancillariidae, but are present in all other taxa, as indicated by plus and minus signs on the right; 2 - Agaronia propatula with prey in a metapodial pouch (asterisk; from Supplemental Video 1) cies (Olivinae; Olsson \& Crovo 1968, ZeIglen \& PORRECA 1969, TURSCH 1991, TAYLOR \& GLOVER 2000, KANTOR \& TURSCH 2001). The animals usually rest burrowed in the sediment, but emerge as soon as they sense the presence of food olfactorily. They then cruise rapidly on the substrate, apparently unguided by any long-distance sensory capabilities. Upon encountering a potential food item, they seize it with the anterior part of the foot, the propodium. Next, the propodium bends ventrally and backwards to transfer the item to the ventral side of the posterior foot, the metapodium, which simultaneously curves forward to form a more or less spherical pouch that encloses the item. Once the prey is securely stored in this metapodial pouch, Oliva usually burrows into the substrate where it feeds on its catch by inserting its long, protractile proboscis into the pouch. Members of the genus Agaronia (Agaroniinae) exhibit very similar behaviour. The trophic relationships and prey handling of one of them, tentatively identified as A. propatula (Conrad, 1849), have been studied in some detail (CYRUS et al. 2015, ROBINSON \& Peters 2018, VeElenturf \& Peters 2020), and this includes the usage of the metapodial pouch in storing prey (RUPERT \& PETERS 2011, CYRUS et al. 2012). Fig. 2 and Supplemental Video 1 present an example of this behaviour.

As emphasised by KANTOR et al. (2017), all known Olivinae and Agaroniinae are devoid of opercula. Members of other taxa of the Olivoidea generally possess opercula, although some Olivellinae and a few Ancillariidae also appear to lack these structures. The phylogenetic hypothesis shown as Fig. 1 implies that an evolutionary loss of the operculum occurred at least three times independently in the Olividae: at the bases of the Olivinae and the Agaroniinae, and within the Olivellinae. Furthermore, a correlation seems to exist among the Olivoidea between the absence of the operculum and the habit of storing food items in a metapodial pouch (Fig. 1). Kantor and colleagues therefore suggested that "the disappearance of the operculum may be related with this ability to form a pouch by facilitating the bending of the metapodium" (KANTOR et al. 2017: 536). This is a plausible hypothesis; it receives additional support if one considers the Olivancillariinae. This taxon had not been included in the phylogenetic analysis by KANTOR et al. (2017) due to the lack of molecular data (Fig. 1), but it is listed as a fifth subfamily of the Olivoidea on MollusCaBASE (2020). All members of Olivancillaria, the only genus in the Olivancillariidae, lack opercula (TESO \& PASTORINO 2011), and O. auricularia (Lamarck, 1811) stores subdued prey in a metapodial pouch (as Lintricula auricularia; MARCUS \& MARCUS 1959: 105-107 and table 1; for a confirmatory observation, see ROCHABARREIRA 2002). 
Most Olividae have a tropical or subtropical distribution, with few species occurring in temperate waters. One of these exceptions is the Purple Olive, Callianax biplicata (G. B. Sowerby I, 1825), in the subfamily Olivellinae. C. biplicata can be found in large numbers on sandy substrates in the intertidal and shallow subtidal zone along the North American Pacific coast (ABвOTT 1954, OlsSON 1956, POWELL et al. 2020). The shells have been collected and used by indigenous peoples to produce jewellery and ornamental objects since prehistoric times (BENNYHOFF \& HugheS 1987, GrOZA et al. 2011). Previous studies focused on the species' reproductive and developmental biology (EDWARDS 1968, STOHLER 1969), its ecological preferences (EDWARDS 1969a, PHILLIPS 1977a), and its diverse responses to a variety of predators (EDWARDS 1969b, PHILLIPS 1977b). Juvenile animals selectively ingest certain foraminiferans (HICKMAN \& LIPPS 1983), but not much more is known about the feeding behaviour of the species. In particular, metapodial pouches have not been observed in Callianax or any other Olivellinae. Here we present observations of $C$. biplicata that throw additional light on the hypothesis of a possible link between the usage of the metapodial pouch in prey storage and the evolutionary loss of the operculum in the Olividae.

\section{MATERIAL AND METHODS}

This paper compiles observations that are mostly by-products of unrelated studies, but which contribute to our understanding of the feeding behaviour of C. biplicata in its morphological context. The attack of an Agaronia propatula on Olivella semistriata was filmed in the natural habitat at Playa Grande, Guanacaste, Costa Rica, in 2014 (Fig. 2 and Supplemental Video $1)$. The behaviour of $C$. biplicata in aquaria with natural seawater was filmed at the Bodega Marine Laboratory (Bodega Bay, California, USA) in 2012, and at the Bamfield Marine Sciences Centre (Bamfield,
Vancouver Island, British Columbia, Canada) in 2013 (Figs 3-10, 18-26 and Supplemental Videos 2, 3). Videos were taken with various standard digital cameras and were processed using QuickTime v.7.7.9 (www.apple.com/quicktime) and ImageJ v.1.50i (imagej.nih.gov/ij).

Figure 11 shows shells of $C$. biplicata in the mollusc collection of the Burke Museum, University of Washington (Seattle, Washington, USA). Shell structure was studied in material available in the teaching collection of the Biology Department, Purdue
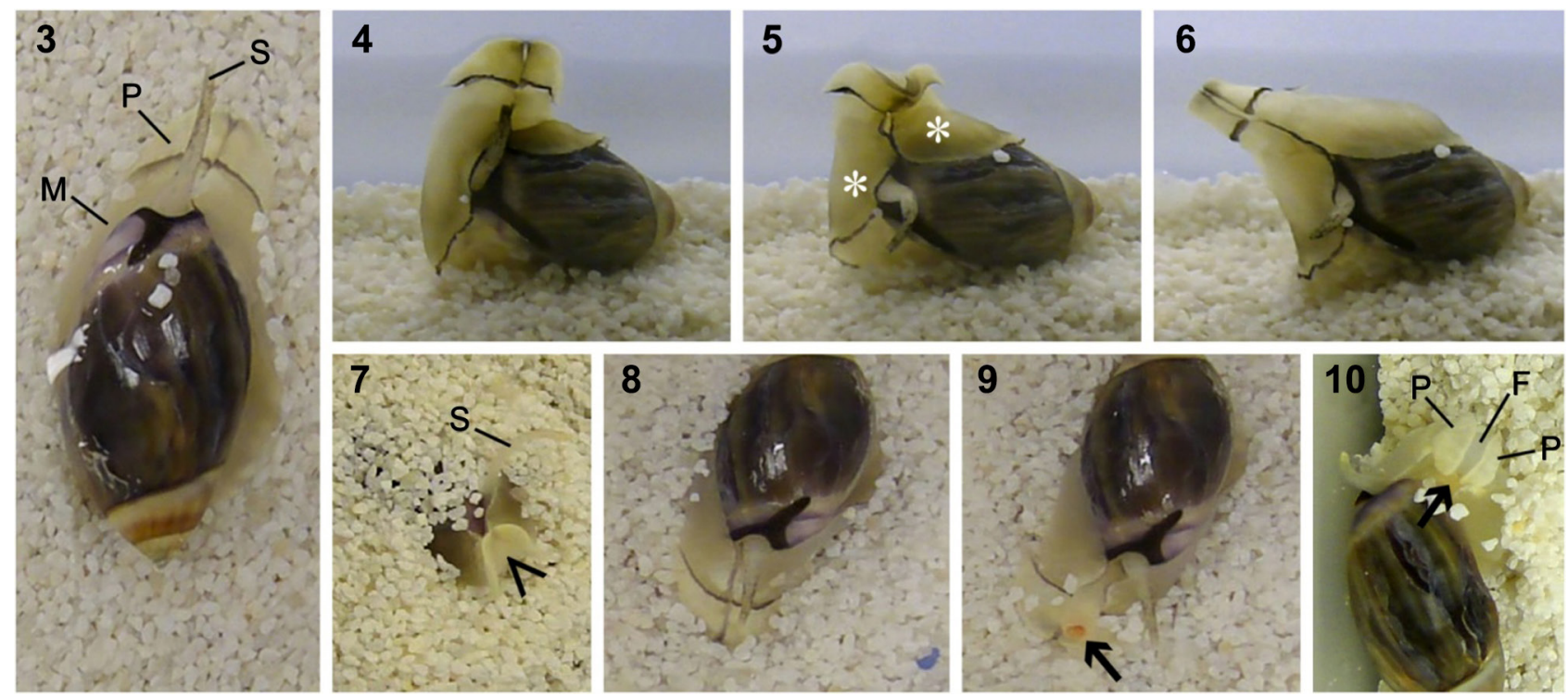

Figs 3-10. General morphology and behaviour of Callianax biplicata: 3 - Crawling animal showing the long siphon (S) and the propodium $(\mathrm{P})$ that is separated from the metapodium $(\mathrm{M})$ by a crescent-shaped groove marked by a darkly pigmented line; 4-6 - Animal demonstrating the flexibility of the foot; note the median longitudinal groove in the propodium and anterior part of the metapodium. The outer edges of the anterior metapodium form parapodia that usually are folded upwards, covering part of the shell (asterisks in 5); 7 - Snail burrowed in the sediment. The siphon (S) protrudes into the water and the propodium is curved upwards (arrowhead pointing to ventral face of the anterior foot); 8, 9 - Crawling snail without (8) and with (9) extended proboscis (arrow); the mouth orifice (9) is visible at the tip of the proboscis; 10 - Animal eating from a food particle $(F)$ held between the left and right halves of the propodium (P; arrow indicates the proboscis). Shell lengths of the animals shown: $16.8 \mathrm{~mm}(3,8,9), 17.2 \mathrm{~mm}(4,5,6,10)$, and $14.8 \mathrm{~mm}$ (7). Figs 3-10 correspond to Supplemental Video 2 

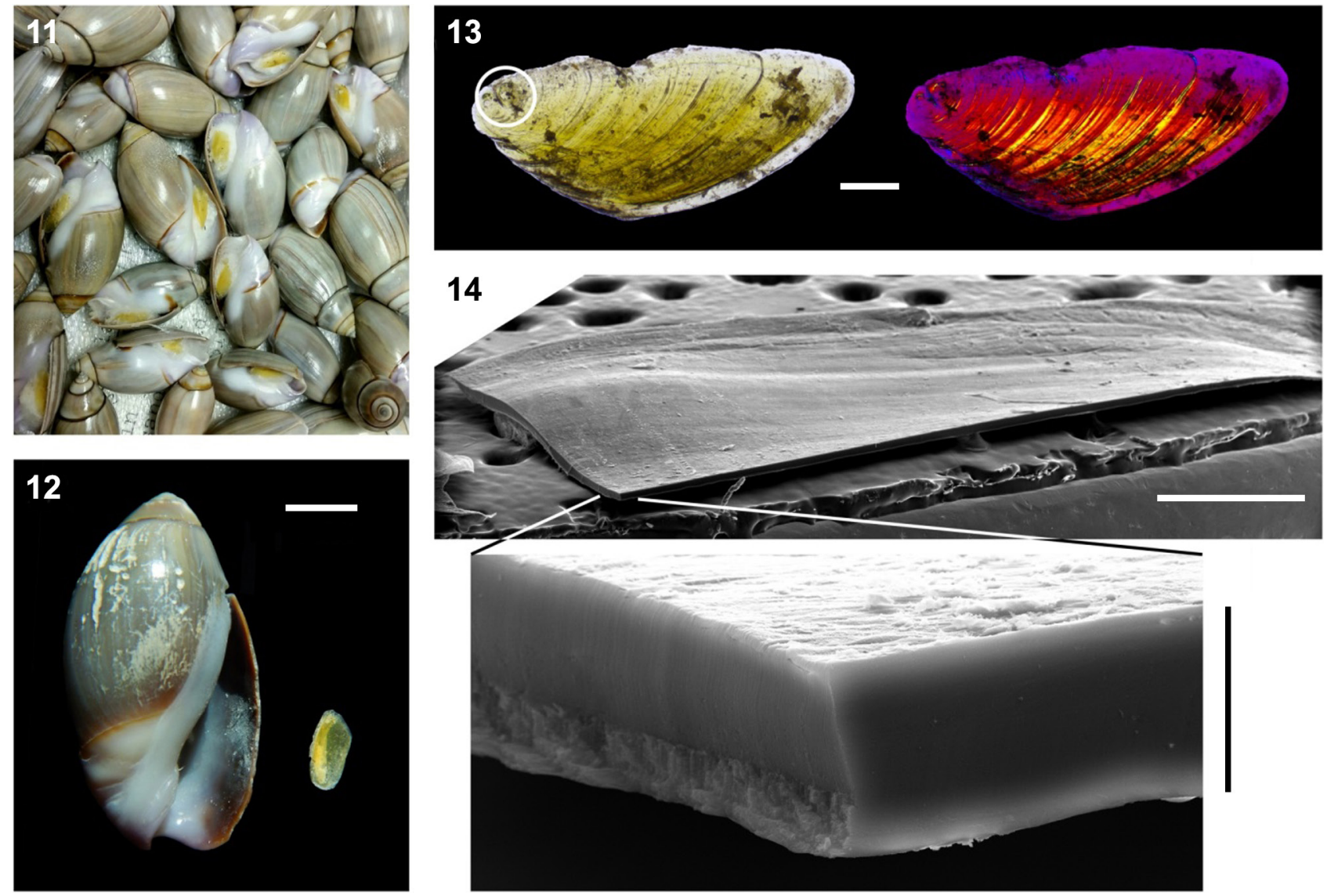

Figs 11-14. The operculum in Callianax biplicata: 11 - Sample of shells with their yellowish opercula attached; 12 Example showing an operculum that is much smaller than the shell aperture; 13 - Opercula are concentric with a marginal nucleus (white circle on the left). They are translucent in plane polarized light (left) and exhibit birefringence in cross-polarized light (right; photographed at the orientation of maximum brightness with 1st order red accessory plate); 14 - Scanning electron micrographs of one quarter of an operculum divided by two perpendicular cuts (top), and magnified view of the corner produced by the cuts (bottom). The dehydrated operculum reaches a maximal thickness of less than $30 \mu \mathrm{m}$ and thins towards its margins. Scale bars: $5 \mathrm{~mm}$ (12), $1 \mathrm{~mm}$ (13), $0.5 \mathrm{~mm}$ (top Fig. 14) and $25 \mu \mathrm{m}$ (bottom Fig. 14)

University Fort Wayne, which originated from Charleston (Oregon, USA; Figs 12, 14), Manzanita (Oregon, USA; Figs 13, 17), and Brady Beach (British Columbia, Canada; Figs 15, 16). The shells were cut open with a hand-held rotary tool (7300 MiniMite; Dremel, Racine, Wisconsin, USA).

For thin-sectioning (Fig. 17), whole animals were dehydrated in an ethanol series and then vacuum-embedded (three cycles of 1 to $0.1 \mathrm{~atm}$ for $4 \mathrm{~min}$ each) in Epo-Tek-301 epoxy resin (Epoxy Technology, Billerica, Massachusetts, USA), followed by curing at room temperature for $24 \mathrm{~h}$. Slices $2 \mathrm{~mm}$ thick were cut perpendicular to the shell axis with a Buehler Isomet 1000 (Buehler, Lake Bluff, Illinois, USA), polished on one side with 600 grit sand paper, glued to a microscope slide, and thinned to $30 \mu \mathrm{m}$ thickness using a Hillquist Thin Section Machine (Hillquist, Arvada, Colorado, USA). Finally, the open surfaces of the sections were polished through a series of grits (600/1000/1200) and finished with aluminium oxide $1 \mu \mathrm{m}$ MicroPolish Suspension (Buehler).
The sections were examined with a DM $2700 \mathrm{P}$ microscope equipped with a DFC 450 camera (Leica Microsystems, Wetzlar, Germany). Isolated opercula preserved in $70 \%$ ethanol were examined in water with the same microscope under standard and cross-polarized illumination (Fig. 13).

For scanning electron microscopy (SEM; Fig. 14), material stored in $70 \%$ ethanol was cut with a razor blade and dehydrated in $80 \%, 90 \%$, and $100 \%$ (3 times) ethanol for 10 minutes each, before drying in a Samdri-PVT-3B Critical Point Dryer (Rockville, Maryland, USA). Specimens mounted on an aluminium SEM stub with double-sided sticky carbon tape were sputter-coated with $4 \mathrm{~nm}$ platinum-palladium using a Cressington High-Resolution Sputter Coater (Watford, UK). Images were taken using an EverhartThornley detector in a Thermo-Fisher Scientific Apreo scanning electron microscope (Thermo-Fisher, Hillsboro, Oregon, USA) using $25 \mathrm{kV}$ and $0.10 \mathrm{nA}$ current. 

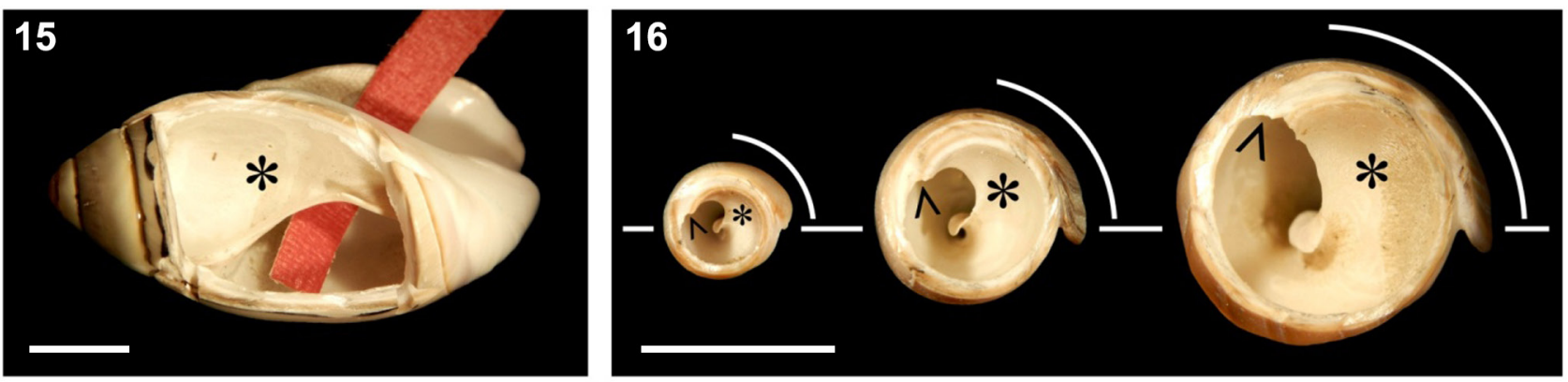

17
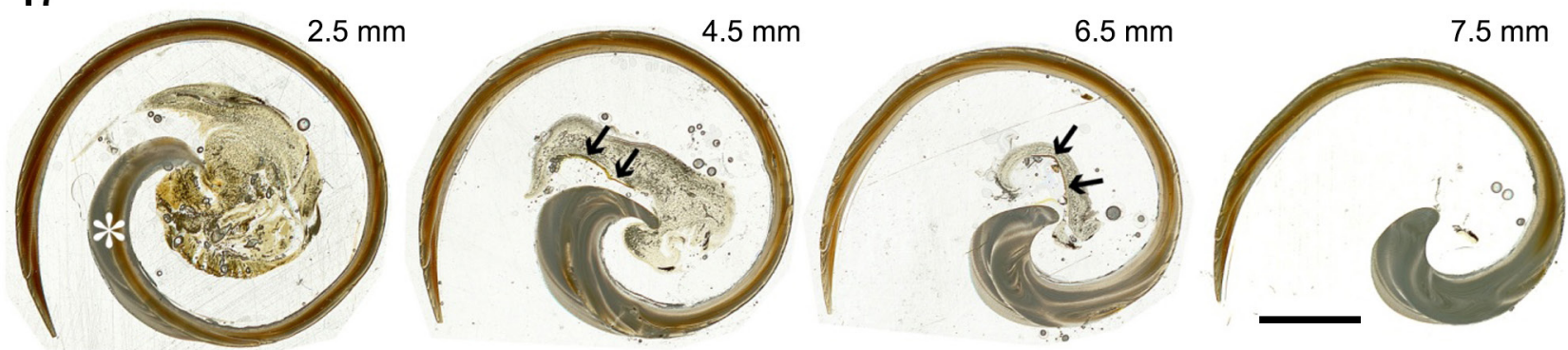

Figs 15-17. Internal shell remodelling in Callianax biplicata: 15 - Shell of $24.7 \mathrm{~mm}$ length with ventral portion of the body whorl removed. Internal shell structures are missing except for a part of the most recent previous whorl which now forms a roof (asterisk) covering the apertural entrance. Red paper strip added to clarify three-dimensional structure; 16 - Anterior views into shells cut open $1 \mathrm{~mm}$ behind the aperture (original shell lengths 13.3, 21.6, and 29.0 mm, from left to right). The advancing resorption of the older whorl forms steps on the internal shell surfaces (arrowheads). Resorption is most advanced in the middle of the roofs over the apertures (asterisks), with angular distances to the posterior edge of the aperture of $85-90^{\circ}$ (indicated by circle segments). This geometry is found in shells of all sizes; 17 - Cross-sections of a fixed specimen (shell length $20 \mathrm{~mm}$ ) at $2.5 \mathrm{~mm}, 4.5 \mathrm{~mm}, 6.5 \mathrm{~mm}$, and $7.5 \mathrm{~mm}$ from the aperture's posterior end (as indicated); the length of the aperture from its posterior end to the shell's base was $10.5 \mathrm{~mm}$. In these posterior views, the outer lip is on the left. Callus is distinguished from other parts of the shell by its characteristic grey colour. Internal shell structures are absent except for the roof covering the aperture (white asterisk). The thin operculum (arrows) shows at $6.5 \mathrm{~mm}$ and $4.5 \mathrm{~mm}$, but not at $2.5 \mathrm{~mm}$ and $7.5 \mathrm{~mm}$, and appears to have deformed together with the soft tissues during preparative dehydration. Scale bars: $5 \mathrm{~mm}(15), 10 \mathrm{~mm}(16)$, $3 \mathrm{~mm}(17)$

\section{RESULTS}

\section{GENERAL MORPHOLOGY AND BEHAVIOUR}

C. biplicata shows the typical morphology of olivid gastropods (Fig. 3; footage from which Figs 3-10 were extracted is compiled in Supplemental Video 2). The bullet-shaped shell, which reaches $30 \mathrm{~mm}$ length from base to apex, is smooth, glossy, and of variable colour ranging from light grey to dark brown. The body lacks a prominent head and cephalic tentacles. The foot consists of a narrow, crescent-shaped propodium, separated by a shallow groove from the large metapodium which has flat lateral parapodia capable of covering most of the shell (Figs 4-6). The propodium is divided lengthwise into halves by a median cleft, and terminates in a free pointed tip on each side (Figs 4,5 ). In many specimens, the edges of both the groove between pro- and metapodium and the longitudinal cleft in the propodium are darkly pigmented, and therefore clearly visible (Figs
3-6). The animal has a long siphon (Fig. 3). Snails kept in tanks with sediment will burrow to assume a resting position. The siphon often protrudes from the sediment, sometimes together with the propodium which is folded lengthwise and bent upwards (Fig. 7); both organs apparently are used to monitor the environment. If in this situation a small piece of shrimp, clam, or fish meat is added to the tank, the snails soon will emerge and begin to search for the food. Like in other olivids (MARCUS \& MARCUS 1959, TURSCH 1991, CYRUS et al. 2012), the propodium seems to be an important sensory organ, as it probes the surroundings continuously (Figs 4-7), especially in crawling animals (Figs 3, 8, 9). The mouth is located at the end of a trunk-like proboscis that can be extended from the most anterior dorsal part of the metapodium between the bases of the parapodia (Fig. 9). Animals feeding on large food items rest next to the object so that their proboscis can access it. 
Smaller food items are often grasped with the propodium, which folds lengthwise so that its left and right halves act against each other, clamping the object between their ventral surfaces. At the same time, the propodium also bends upwards and backwards so that the proboscis can reach the food (Fig. 10).

\section{OPERCULUM STRUCTURE}

C. biplicata is one of the operculate Olivellinae. However, the operculum in this species appears to be smaller than the corresponding shell aperture (Figs 11, 12). The corneous opercula are of the concentric type with pronounced growth lines and a marginal nucleus. They appear translucent in the light microscope (Fig. 13, left) and show birefringence under polarized light illumination (Fig. 13, right). Optical extinction occurs when the direction of growth is parallel to one of the polarizing filters, and maximum brightness (as seen in Fig. 13, right) when the filters are at $45^{\circ}$ to the growth direction. This suggests optical axes aligned along the direction of growth, perpendicular to the growth lines. Most opercula are about twice as long as they are wide, but their shapes vary widely. They appear to fray along the edges and are flexible and fragile when isolated. Scanning electron micrographs of cut opercula suggest that they are not more than $30 \mu \mathrm{m}$ thick (Fig. 14). However, fixation for the SEM includes dehydration, and it is possible that fully hydrated opercula are somewhat thicker.

\section{SHELL REMODELLING}

Older whorls do not persist as internal shell structures but are mostly resorbed. The only remaining internal component is a part of the wall of the most recently overgrown whorl which forms a cover or roof over the apertural entrance (Fig. 15). When viewed along the axis of a shell cut open just above the posterior end of the aperture, this older wall is seen extending in the counter-clockwise direction from the aperture (Fig. 16). The inward-facing edge of this wall is curved. In its centre, it reaches to about $85^{\circ}$ measured from the posterior (upper) edge of the aperture, while it merges with the inner surface of the body whorl at around $160^{\circ}$. This geometry was observed in shells of all available sizes (13 to $29 \mathrm{~mm}$ shell length; Fig. 16).

An operculum that is smaller than the aperture itself may still close the aperture if the apertural channel constricts in the inward direction and the animal withdraws far enough into its shell. To see whether
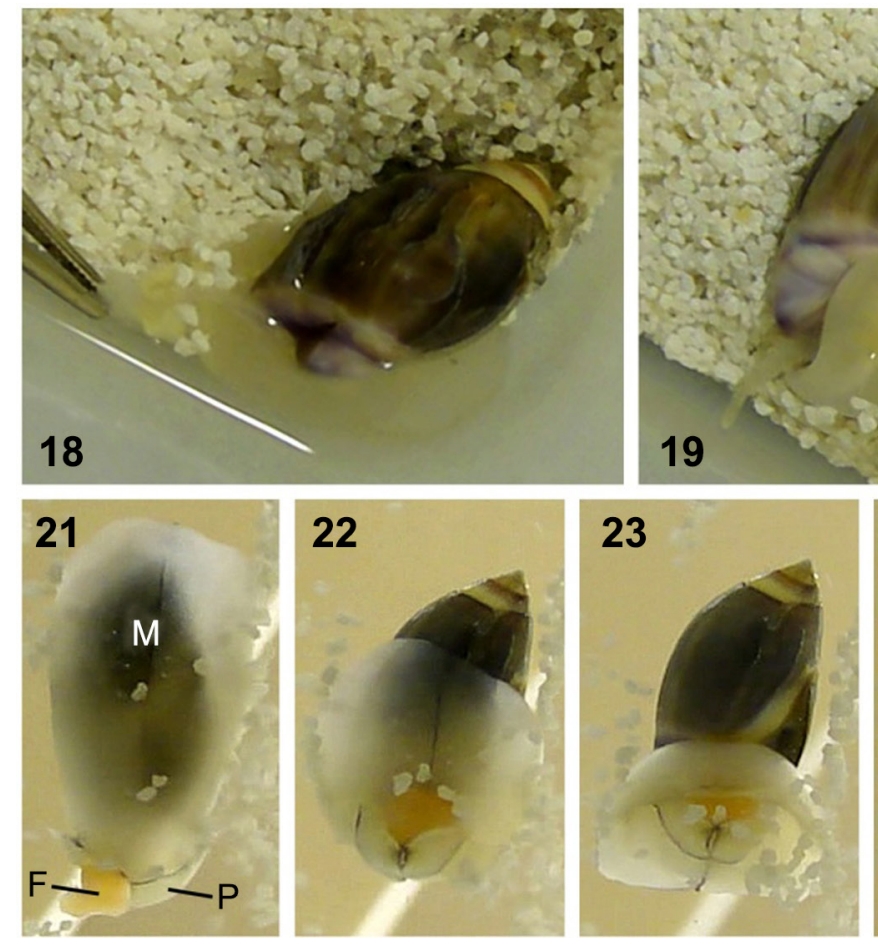
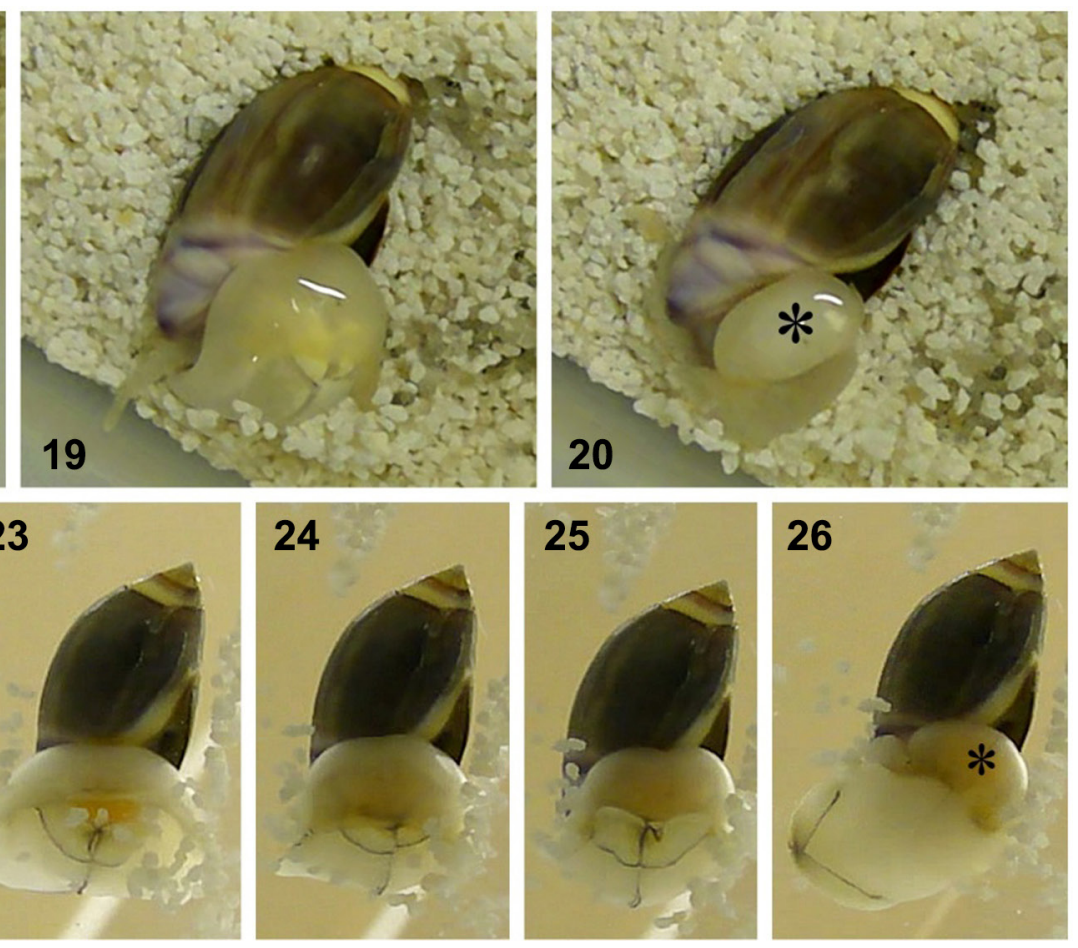

Figs 18-26. Callianax biplicata stores food in a pouch formed by the posterior metapodium: 18-20 - A snail reaches with its propodium for a food item offered with forceps (18). Then the anterior foot holding the item bends toward the ventral side of the posterior metapodium, which forms a pouch around propodium and food item (19). Finally the propodium is withdrawn and the snail starts burrowing while the food remains secured in the metapodial pouch (asterisk; 20, 26); 21-26 - Stages of pouch formation recorded from below in a glass bottom aquarium (F, food item; M, metapodium; P, propodium). Shell lengths of the animals shown: $16.8 \mathrm{~mm}$ (18-20), $17.6 \mathrm{~mm}$ (21-26). Figs 18-26 correspond to Supplemental Video 3 
this might be the case in C. biplicata, we produced serial shell sections. The sections confirmed not only that the aperture opened into a single, coherent cavity, but also demonstrated that the apertural channel widened rather than narrowed from the aperture inwards (Fig. 17).

\section{FORMING A METAPODIAL POUCH}

In animals kept in tanks, we repeatedly observed storage of food items in metapodial pouches (Figs 18-26 were extracted from the footage compiled in Supplemental Video 3). In the example shown in Figs 18-20, the snail reaches with its propodium for a small piece of shrimp meat offered with forceps, grabs the food, and bends the anterior part of its foot ventrally and posteriorly. At the same time, the posterior part of the foot bends ventrally while its margin contracts so that a sack-like cavity is produced. The anterior foot with the food item is inserted into this cavity, where it remains visible due to the partial translucence of the metapodium (Fig. 19). Next, the

\section{DISCUSSION}

\section{A LITTLE OLIVA}

Etymologically, olivella is a Latin diminutive of oliva, and indeed, C. (formerly Olivella) biplicata behaves much like a little Oliva. Not only does it grab and manipulate food items with an 'opposable propodium' (Fig. 10), it also stores the food in a pouch formed by the posterior metapodium, just as Oliva and Agaronia do. The body movements which the operculate $C$. biplicata performs to form the pouch and transfer food into it (Figs 18-26, Supplemental Video 3 ) are essentially the same as those previously documented for the inoperculate Olivinae (OLSSON \& Crovo 1968, ZeIgler \& Porreca 1969, KANTOR \& TURSCH 2001), Agaroniinae (RUPERT \& PETERS 2011, Cyrus et al. 2012; Fig. 2, Supplemental Video 1 ), and probably also the Olivancillariinae (MARCUS \& MARCUS 1959).

Filled metapodial pouches look like swellings of the snail's body (Supplemental Video 1), which has lead to misinterpretations. OLSSON (1956: 164) observed Oliva undatella (Lamarck, 1811) attacking the smaller Olivella semistriata (Gray, 1839; probably Olivella columellaris, G. B. Sowerby I, 1825; compare TROOST et al. 2012) on a beach in Ecuador. He reported that "the smaller shell would be swallowed whole, the body of the Oliva swelling into a large, rounded, ball-like mass". This appears implausible, particularly since the live victims could be "freed shortly after having been swallowed". Olsson (1956) did not specify what exactly he did to "free" the Olivella, but propodium releases the item and the anterior foot is withdrawn. Simultaneously, the margin of the posterior foot continues to contract, reminiscent of a drawstring bag, and firmly encloses the food item. In this way, a metapodial pouch (asterisk in Figs 20, 26) is formed.

In tanks containing sand, snails forming metapodial pouches had to be turned over in order to witness the entire procedure (Figs 18-20, and the corresponding first part of Supplemental Video 3). To observe the behaviour in undisturbed animals, we filmed the process from below an aquarium with glass bottom and without sand. The snails performed the same sequence of movements as described above to deposit food in their metapodial pouches (Figs 21-26).

Feeding by introduction of the proboscis into the metapodial pouch was not observed. The animals rather released food from the metapodial pouch, seized it with the propodium, and fed as described above (Fig. 10).

we note that olivid predators readily release the contents of their metapodial pouches if disturbed following a catch. Considering this example, it seems possible that pouch formation especially in small olivids, like the operculate $C$. biplicata, may have been observed but misinterpreted in the past.

In any case, our observations indicate that the correlation between the inoperculate state and the ability to form metapodial pouches for food storage in the Olividae is not as strict as our graphic representation (Fig. 1) of the hypothesis by KANTOR et al. (2017) had suggested. What do we know about function and structure of the operculum in C. biplicata?

\section{PROTECTIVE FUNCTIONS OF THE OPERCULUM}

It is sometimes claimed to be "axiomatic that shells provide protection for gastropods by enclosing the soft tissues. [...] To complete the protection offered by the shell, the operculum should be strong and fit tightly into the aperture" (PAUL 1991: 127-128). Concerning this protective function of the operculum that "fits like a door across the shell aperture after the snail has withdrawn" (HuGHES 1986: 10), CHECA \& JIMÉNEZ-JIMÉNEZ (1998) distinguished two morphofunctional types. Rigiclaudent opercula are comparatively solid, as the name suggests. They have the size and cross-sectional shape of the path they are supposed to block, and may in fact fit like a rigid door. In contrast, flexiclaudent opercula are elastic and often larger than the shape of the path 
they block; they do not necessarily have the exact shape of that path. Flexiclaudent opercula may bend as they are pressed against the apertural walls when the animal retracts, and the overlapping edges curve outward, sealing the aperture. Only rigiclaudent opercula can be calcified, while flexiclaudent ones generally are corneous, for obvious reasons.

The assumed protective function of both types of opercula is threefold. Firstly, opercula are thought to prevent predatory attacks through the aperture (HUGHES 1986, CHECA \& JIMÉNEZ-JIMÉNEZ 1998). However, unequivocal quantitative evidence demonstrating an operculum's efficiency in the prevention of predation in natural habitats has been produced in only a few cases (e.g., SNYDER \& KALE 1983). Even in the probably most convincing example for an efficient anti-predator function of an operculum in the wild (GIBSON 1970), the dog-whelk Nucella lapillus (Linnaeus, 1758; formerly included in the genera Purpura and Thais), significant proportions of natural populations possess opercula that are too small to block the aperture, or lack opercula altogether (COLGAN 1910, CoOKE 1917, KePPENS et al. 2008). Secondly, tightly fitting opercula can prevent the entrance of harmful fluids such as digestive juices into the shell, and have been interpreted as essential for the ability of some operculate gastropods to survive passage through the digestive tract of birds and fishes (NORTON 1988, BROWN 2007, CADÉE 2011). However, some small eupulmonates accomplish the same (WADA et al. 2012), although mature Eupulmonata generally lack opercula (GITTENBERGER 1996). Thirdly, opercula have been hypothesised to reduce water loss in animals exposed to dehydrating conditions (MCQUAID 1982, PAUL 1991). While this physical effect certainly can be observed in experimental settings, its physiological relevance under natural conditions has been questioned (GIBSON 1970, GITTENBERGER 1996). In any case, opercula might serve any of the three protective functions if they are flexiclaudent or rigiclaudent, but not if they are too small to occlude the aperture, in other words, if they are 'aclaudent'.

The operculum of C. biplicata is non-calcified and flexible, but it appears to be aclaudent rather than flexiclaudent due to its comparatively small size (Figs $11,12,17)$; see also images of the species in HoLM (2007, as Olivella biplicata) and Powell et al. (2020: figs $22 \mathrm{~A}$ and $23 \mathrm{~A}$ ). Therefore a protective function of the operculum that depends on the tight occlusion of the aperture is unlikely, based on the specimens we have examined. One may argue that if the diameter of the whorl decreases in the inward direction, even a relatively small operculum could block the entrance path if the animal only retracts far enough. This argument may apply to gastropods which retain older whorls as internal shell structures (EDGELL
\& MIYASHITA 2009), but not to those that partially or wholly resorb older whorls that have become overgrown and thus internalised by younger whorls (KOHN et al. 1979, SOLEM 1983). Interior shell remodelling occurs in Oliva (ZEIGLER \& PORRECA 1969: 78), and the near complete resorption of the inner walls of older whorls had been recognised as a character of the Olivellinae (formerly family Olivellidae) by KANTOR (1991). In fact, C. biplicata resorbs older, internal shell components almost entirely, turning the shell interior into a single coherent space (Figs 15-17). Shells of all sizes examined exhibited the same internal geometry (Fig. 16), indicating that the breakdown of older whorls proceeds in step with shell growth. The inward passage from the outer edge of the aperture into the shell's interior therefore widens rather than shrinks in shells of all sizes. Consequently, the operculum in C. biplicata cannot function like a door that seals the shell interior at a distance from the aperture. The conclusion that the operculum has no protective function in the species is supported also by the small thickness of the operculum (Fig. 14).

\section{OPERCULUM ULTRASTRUCTURE}

In developmental studies, larval opercula routinely are identified by their birefringence (CLEMENT 1986, SWEET 1998). We are not aware, though, of systematic investigations into the causes of birefringence in corneous opercula of mature gastropods, as detected in C. biplicata (Fig. 13). Corneous opercula consist of operculins, scleroproteins which resemble collagen (HUNT 1970, 1976). Collagens assemble into fibrillar arrays of high molecular order which show both intrinsic and form birefringence (for a brief technical introduction, see WOLMAN \& KASTEN 1986). Operculins may develop similar molecular arrangements. Our scanning electron micrographs could not be expected to resolve any crystal-like molecular order causing birefringence in opercula of $C$. biplicata (Fig. 14). Generally, further insights into the molecular structure of corneous opercula are desirable. As a simple and inexpensive method for acquiring information on sub-microscopic structures without any damaging preparation of valuable specimens, polarized light microscopy could facilitate comparative studies on the structure, mechanics, and evolution of corneous opercula in the Olividae and other taxa.

\section{METAPODIUM BIOMECHANICS AND THE OPERCULUM}

The formation of the metapodial pouch in the Olividae including $C$. biplicata requires ventral bending as well as contraction along the margin of the posterior metapodium (Figs 18-26, Supplemental 
Videos 1, 3). To evaluate the biomechanical effects an operculum might have on the process, we have to remember that opercula connect to the foot at the opercular disc, a specialised epithelium which is histologically distinct from the regular dorsal foot integument (CHECA \& JIMÉNEZ-JIMÉNEZ 1998). Because the opercular disc usually lies on or close to the mid-sagittal line on the foot surface, it appears unlikely that an operculum could interfere mechanically with contractions of the foot's margins. On the other hand, an inflexible operculum certainly could prevent any bending of the opercular disc. It must be noted, though, that the opercular disc is always smaller than the area of the operculum (CHECA \& JIMÉNEZ-JIMÉNEZ 1998). Therefore the presence of even a very large operculum does not necessarily imply a limited ability for ventral bending of the posterior foot; direct observations of live animals will be necessary to evaluate the operculum's biomechanical effects. Our observations of live C. biplicata demonstrated that the operculum does not affect the ability to form a metapodial pouch in this species.

An operculum also may have indirect mechanical effects. When the metapodium bends ventrally as in forming a pouch, the part of the operculum that is unconnected to the integument might protrude from the pouch's curved surface and become entangled with sediment, inhibiting locomotion and burrowing. Again, this does not seem to apply to C. biplicata, which we observed moving and burrowing into the sediment without apparent difficulties while carrying food in its pouch.

As larvae, all gastropods are operculate (PONDER \& LINDBERG 1997), and various structural and developmental aspects of larval opercula have attracted scrutiny (BONAR 1978, KANO 2006, HASHIMOTO et al. 2012). The operculum in adult C. biplicata may represent a vestigial organ or, more precisely, an ontogenetic remnant that had functional significance at early life stages but no discernible function at maturity. For example, major muscles involved in the retraction of the foot into the protoconch attach to the operculum in larvae of various gastropod taxa (BONAR \& HADFIELD 1974, EVANS et al. 2009, PAGE \& FERGUSON 2013). It is unclear whether the operculum in mature C. biplicata and other operculate Olivoidea also functions as an exoskeletal attachment point for muscles. If it does, the evolutionary loss of the operculum in the Olividae would appear to have depended on modifications of the muscular system that rendered the opercular attachment dispensable. In this context it is of interest that the body movements which the inoperculate Agaronia propatula performs when it withdraws into its shell seem to differ from those observed in several operculate Olivella species (RUPERT \& PETERS 2011). We will need sufficiently detailed anatomical data concerning the muscular systems of various Olividae, together with comparative kinematic analyses of their movement patterns, to develop a biomechanically sound reconstruction of the multiple independent losses of the operculum that seem to have occurred in this family.

\section{ACKNOWLEDGEMENTS}

We thank Melissa A. FREY (Burke Museum of Natural History and Culture, Seattle, Washington, USA) and GeORge Holm (Pacific Northwest Shell Club, Seattle, Washington, USA) for helpful discussion during early stages of this project, and YURI I. KANTOR (A. N. Severtzov Institute of Ecology and Evolution, Russian Academy of Sciences, Moscow, Russia) for his valuable comments on a manuscript draft. Technical support from the Franceschi Microscopy \& Imaging Center at Washington State University (Pullman, Washington, USA) is gratefully acknowledged.

\section{REFERENCES}

AввотT R. T. 1954. American seashells. D. van Nostrand Co., Princeton NJ, USA.

BenNYHOFF J. A., Hughes R. E. 1987. Shell bead and ornament exchange networks between California and the western Great Basin. Anthropological Papers of the American Museum of Natural History 64: 79-175.

BONAR D. B. 1978. Fine structure of muscle insertions on the larval shell and operculum of the nudibranch Phestilla sibogae (Mollusca: Gastropoda) before and during metamorphosis. Tissue and Cell 10: 143-152. https://doi.org/10.1016/0040-8166(78)90013-7

BONAR D. B., HADFIELD M. G. 1974. Metamorphosis of the marine gastropod Phestilla sibogae Bergh (Nudibranchia: Aeolidacea). I. Light and electron microscopic anal-

ysis of larval and metamorphic stages. Journal of Experimental Marine Biology and Ecology 16: 227-255. https://doi.org/10.1016/0022-0981(74)90027-6

BOUCHET P., RocROI J. P. 2005. Classification and nomenclator of gastropod families. Malacologia 47: 1-397.

BROWN R. J. 2007. Freshwater mollusks survive fish gut passage. Arctic 60: 124-128. https://doi.org/10.14430/arctic237

CADÉE G. C. 2011. Hydrobia as "Jonah in the whale": shell repair after passing through the digestive tract of shelducks alive. Palaios 26: 245-249. https://doi.org/10.2110/palo.2010.p10-095r 
CHECA A. G., JiMÉNEZ-JiMÉNEZ A. P. 1998. Constructional morphology, origin, and evolution of the gastropod operculum. Paleobiology 24: 109-132. https://doi.org/10.1017/S0094837300020005

Clement A. C. 1986. The embryonic value of the micromeres in Ilyanassa obsoleta, as determined by deletion experiments. II. The second quartet cells. International Journal of Invertebrate Reproduction and Development 9: 139-153. https://doi.org/10.1080/01688170.1986.10510192

Colgan N. 1910. Notes on the adaptability of certain littoral Mollusca. The Irish Naturalist 19: 127-133. https://www.jstor.org/stable/25523651

COOKE A. H. 1917. A colony of Nucella (olim Purpura) lapillus (Linn.) with operculum malformed or absent. Proceedings of the Malacological Society of London (Journal of Molluscan Studies) 12: 231-232. https://doi.org/10.1093/oxfordjournals.mollus.a063645

Cyrus A. Z., Rupert S. D., Silva A. S., Graf M., RAppaport J. C., PAladino F. V., Peters W. S. 2012. The behavioural and sensory ecology of Agaronia propatula (Caenogastropoda: Olividae), a swash-surfing predator on sandy beaches of the Panamic faunal province. Journal of Molluscan Studies 78: 235-245. https://doi.org/10.1093/mollus/eys006

Cyrus A. Z., SWIGGS J., SANTIDRIAN TOMILLO P., PALADINO F. V., Peters W. S. 2015. Cannibalism causes sizedependent intraspecific predation pressure but does not trigger autotomy in the intertidal gastropod Agaronia propatula. Journal of Molluscan Studies 81: 388-396. https://doi.org/10.1093/mollus/eyv007

Edgell T. C., MiYashita T. 2009. Shell shape and tissue withdrawal depth in 14 species of temperate intertidal snails. Journal of Molluscan Studies 75: 235-240. https://doi.org/10.1093/mollus/eyp018

EDWARDS D. C. 1968. Reproduction in Olivella biplicata. The Veliger 10: 297-304.

EDWARDS D. C. 1969a. Zonation by size as an adaptation for intertidal life in Olivella biplicata. American Zoologist 9: 399-417. https://doi.org/10.1093/icb/9.2.399

EDWARDS D. C. 1969b. Predators on Olivella biplicata, including a species-specific predator avoidance response. The Veliger 11: 326-333.

Evans C. C. E., Dickinson A. J. G., Croll R. P. 2009. Major muscle systems in the larval caenogastropod, Ilyanassa obsoleta, display different patterns of development. Journal of Morphology 270: 1219-1231. https://doi.org/10.1002/jmor.10751

GiBSON J. S. 1970. The function of the operculum of Thais lapillus (L.) in resisting desiccation and predation. Journal of Animal Ecology 39: 159-168. https://doi.org/10.2307/2893

GiTTENBERGER E. 1996. Adaptations of the aperture in terrestrial gastropod-pulmonate snails. Netherlands Journal of Zoology 46: 191-205. https://doi.org/10.1163/156854295X00159

Groza R. G., Rosenthal J., Southon J., Milliken R. 2011. A refined shell bead chronology for late Holocene central California. Journal of California and Great Basin Anthropology 31: 135-154.

https://www.jstor.org/stable/23215648

HASHIMOTO N., KURITA Y., WADA H. 2012. Developmental role of $d p p$ in the gastropod shell plate and co-option of the $d p p$ signaling pathway in the evolution of the operculum. Developmental Biology 366: 367-373. https://doi.org/10.1016/j.ydbio.2012.04.010

HICKMAN C. S., LIPPS J. H. 1983. Foraminiferivory: selective ingestion of foraminifera and test alterations produced by the neogastropod Olivella. Journal of Foraminiferal Research 13: 108-114. https://doi.org/10.2113/gsjfr.13.2.108

Holm G. P. 2007. About Olivella pycna Berry, 1935, least known of the Pacific Northwest olives. Dredgings 47: 4-5.

HUGHES R. N. 1986. A functional biology of marine gastropods. Johns Hopkins University Press, Baltimore MD, USA.

HUNT S. 1970. Invertebrate structure proteins. Characterization of the operculum of the gastropod mollusc Buccinum undatum. Biochimica et Biophysica Acta 207: 347-360. https://doi.org/10.1016/0005-2795(70)90027-9

HUNT S. 1976. The gastropod operculum: a comparative study of the composition of gastropod opercular proteins. Journal of Molluscan Studies 42: 251-260. https://doi.org/10.1093/oxfordjournals.mollus.a065331

KANO Y. 2006. Usefulness of the opercular nucleus for inferring early development in neritimorph gastropods. Journal of Morphology 267: 1120-1136. https://doi.org/10.1002/jmor.10458

KANTOR YU. I. 1991. On the morphology and relationships of some oliviform gastropods. Ruthenica 1: 17-52.

Kantor Yu. I., Fedosov A. E., Puillandre N., Bonillo C., BOUCHET P. 2017. Returning to the roots: morphology, molecular phylogeny and classification of the Olivoidea (Gastropoda: Neogastropoda). Zoological Journal of the Linnean Society 180: 493-541. https://doi.org/10.1093/zoolinnean/zlw003

KANTOR YU. I., TURSCH B. 2001. Feeding. In: TURSCH B., GREIFENEDER D. (eds). Oliva shells. The genus Oliva and the species problem. L'Informatore Piceno, Ancona, Italy, pp. 209-216.

KePPENS M., DHONDT K., MIENIS H. K. 2008. The variability of the operculum in Nucella lapillus (Gastropoda, Muricidae) from a colony in Audresselles, France. Vita Malacologica 7: 15-20.

KoHn A. J., Myers E. R., MEenAKSHI V. R. 1979. Interior remodeling of the shell by a gastropod mollusc. Proceedings of the National Academy of Sciences of the United States of America 76: 3406-3410. https://doi.org/10.1073/pnas.76.7.3406

MARCUS E., MARCUS E. 1959. Studies on Olividae. Boletim da Faculdade de Filosofia, Ciências e Letras, Universidade de São Paulo, Zoologia 22: 99-188. https://doi.org/10.11606/issn.2526-3382.bffclzoologia. 1959.120324 
MCQUAID C. D. 1982. The influence of desiccation and predation on vertical size gradients in populations of the gastropod Oxystele variegata (Anton) on an exposed rocky shore. Oecologia 53: 123-127.

https://doi.org/10.1007/BF00377146

MollusCaBASE 2020. MolluscaBase. Olivoidea Latreille, 1825. Available online at World Register of Marine Species at http://www.marinespecies.org/ (accessed 11 August 2020).

NORTON S. F. 1988. Role of the gastropod shell and operculum in inhibiting predation by fishes. Science 241: 92-94. https://doi.org/10.1126/science.241.4861.92

OlsSON A. A. 1956. Studies on the genus Olivella. Proceedings of the Academy of Natural Sciences of Philadelphia 108: 155-225. https://www.jstor.org/stable/4064521

Olsson A. A., Crovo L. E. 1968. Observations on aquarium specimens of Oliva sayana. The Veliger 11:31-32.

PAge L. R., Ferguson S. J. 2013. The other gastropod larvae: larval morphogenesis in a marine neritomorph. Journal of Morphology 274: 412-428. https://doi.org/10.1002/jmor.20103

PAUL C. R. C. 1991. The functional morphology of gastropod apertures. In: SCHMIDT-KITTLER N., VOGEL K. (eds). Constructional morphology and evolution. Springer, Berlin, Germany, pp. 127-140. https://doi.org/10.1007/978-3-642-76156-0_10

PHILliPS D. W. 1977a. Activity of the gastropod mollusk Olivella biplicata (Sowerby) in response to a natural light/dark cycle. The Veliger 20: 137-143.

PHILLIPS D. W. 1977b. Avoidance and escape responses of the gastropod mollusc Olivella biplicata (Sowerby) to predatory asteroids. Journal of Experimental Marine Biology and Ecology 28: 77-86.

https://doi.org/10.1016/0022-0981(77)90064-8

PONDER W. F., LINDBERG D. R. 1997. Towards a phylogeny of gastropod molluscs: an analysis using morphological characters. Zoological Journal of the Linnean Society 119: 83-265. https://doi.org/10.1111/j.1096-3642.1997.tb00137.x

Powell C. L., Vervaet F., Berschauer D. 2020. A taxonomic review of California Holocene Callianax (Olivellidae: Gastropoda: Mollusca) based on shell characters. Festivus, Special Issue March: 2-38.

Robinson N. J., Peters W. S. 2018. Complexity of the prey spectrum of Agaronia propatula (Caenogastropoda: Olividae), a dominant predator in sandy beach ecosystems of Pacific Central America. PeerJ 6: e4714. https://doi.org/10.7717/peerj.4714

ROCHA-BARREIRA C. D. A. 2002. Feeding behaviour of Olivancillaria vesica auricularia (Lamarck, 1810) (Mollusca, Olividae). Thalassas 18: 83-89.

Rupert S. D., Peters W. S. 2011. Autotomy of the posterior foot in Agaronia (Caenogastropoda: Olividae) occurs in animals that are fully withdrawn into their shells. Journal of Molluscan Studies 77: 437-440. https://doi.org/10.1093/mollus/eyr019
SNYDER N. F. R., KALE H. W. 1983. Mollusk predation by snail kites in Colombia. Auk 100: 93-97.

https://doi.org/10.1093/auk/100.1.93

SOLEM A. 1983. Lost or kept internal whorls: ordinal differences in land snails. Journal of Molluscan Studies Supplement 12A: 172-178.

https://doi.org/10.1093/oxfordjournals.mollus.a065740

SterbA G. W. 2004. Olividae. A collectors guide. ConchBooks, Hackenheim, Germany.

STOHLER R. 1969. Growth study in Olivella biplicata (Sowerby, 1825). The Veliger 11: 259-267.

SWEET H. C. 1998. Specification of first quartet micromeres in Ilyanassa involves inherited factors and position with respect to the inducing $\mathrm{D}$ macromere. Development 125: 4033-4044.

TAYlor J. D., Glover E. A. 2000. Diet of olives: Oliva tigridella Duclos, 1835 in Queensland. Molluscan Research 20: 19-24. https://doi.org/10.1080/13235818.2000.10673729

TESO V., PAstorino G. 2011. A revision of the genus Olivancillaria (Mollusca, Olividae) from the southwestern Atlantic. Zootaxa 2889: 1-34. https://doi.org/10.11646/zootaxa.2889.1.1

Troost A. I., Rupert S. D., Cyrus A. Z., PAladino F. V., DATTILO B. F., PETERS W. S. 2012. What can we learn from confusing Olivella columellaris and $O$. semistriata (Olivellidae, Gastropoda), two key species in Panamic sandy beach ecosystems? Biota Neotropica 12: 101-113. https://doi.org/10.1590/S1676-06032012000200011

TURSCH B. 1991. Studies on Olividae. XIII. Behaviour of Oliva vidua in aquarium: preliminary observations. Apex 6: 1-10.

TURSCH B., GREIFENEDER D. 2001. Oliva shells. The genus Oliva and the species problem. L'Informatore Piceno, Ancona, Italy.

Veelenturf C. A., Peters W. S. 2020. Size-dependent locomotory performance creates a behaviorally mediated prey size refuge in the marine snail Olivella semistriata: a study in the natural habitat. Current Zoology 66: 57-62. https://doi.org/10.1093/cz/zoz022

WADA S., KAWAKAMI K., CHIBA S. 2012. Snails can survive passage through a bird's digestive system. Journal of Biogeography 39: 69-73.

https://doi.org/10.1111/j.1365-2699.2011.02559.x

WOLMAN M., KASTEN F. H. 1986. Polarized light microscopy in the study of the molecular structure of collagen and reticulin. Histochemistry 85: 41-49. https://doi.org/10.1007/BF00508652

Zeigler R. F., Porreca H. C. 1969. Olive shells of the world. Shell Cabinet, Falls Church VA, USA.

Received: November 16th, 2020

Revised: January 6th, 2021

Accepted: January 25th, 2021

Published on-line: March 19th, 2021 


\section{SUPPLEMENTAL VIDEOS}

Feeding behaviour and the operculum in Callianax biplicata (G. B. Sowerby 1, 1825) (Supplemental Video 1, corresponds to Fig. 2).

Feeding behaviour and the operculum in Callianax biplicata (G. B. Sowerby 1, 1825) (Supplemental Video 2, corresponds to Figs 3-10). The video runs at double speed.

Feeding behaviour and the operculum in Callianax biplicata (G. B. Sowerby 1, 1825) (Supplemental Video 3, corresponds to Figs 18-26). The video runs at double speed. 